ESJ Humanities

\title{
The Strategic Obstacles Preventing Israel's Attack on Iran's Nuclear Reactors
}

\author{
Jihad Aldeen Albadawi, MA International Studies \\ Birzeit University, Palestine
}

Doi:10.19044/esj.2021.v17n33p107

Submitted: 23 July 2021

Accepted: 13 September 2021

Published: 30 September 2021
Copyright 2021 Author(s)

Under Creative Commons BY-NC-ND

4.0 OPEN ACCESS

Cite As:

Albadawi J.A. (2021). The Strategic Obstacles Preventing Israel's Attack on Iran's Nuclear Reactors. European Scientific Journal, ESJ, 17 (33), 107.

https://doi.org/10.19044/esj.2021.v17n33p107

\begin{abstract}
The study analyzes the reasons that prevent "Israel" from launching a comprehensive military strike against the nuclear sites and other vital sites of a military nature in Iran, in light of the escalation of the indirect military confrontation between them in many conflicts in the Middle East. The study summarizes the "Israeli" risks to implementing "preventive war" on the Iranian scene in four obstacles, which are: the operational, the legal, the military, and the armed non-state actors. The study concluded that: despite the blockade imposed on Iran, especially with regard to the import of advanced military equipment, Iran was able to build a relative deterrent force consisting of three pillars, which rest on its ability to (1) threaten navigation through the Strait of Hormuz, (2) undertake terrorist attacks on multiple continents, and (3) conduct long-range strikes, primarily by missiles (or with rockets owned by proxies deployed in many countries of the Middle East, and its ability to target "Israel" with short and medium-range ballistic missiles. The Iranian deterrent force, or what has come to be called the Iran's deterrence triad, was the real obstacle to Israel from launching a preventive war against Iran.
\end{abstract}

Keywords: Iran, Israel, the Begin Doctrine, preventive war, force, strategic barriers

\section{Introduction}

The "Israeli" Prime Minister Menahem Begin drafted the unofficial doctrine that is named for him, "the Begin Doctrine," seeking to prevent 
countries hostile to Israel calling for its destruction from developing a nuclear military capability. To that end, Israel destroyed the reactor in Iraq in 1981, and the scenario was repeated in 2007 when it took control over major areas of Syria (including over the actual Syrian reactor site in Deir ez-Zor). "Israel" commented on the military strike on the Iraqi nuclear reactor, saying: "We will not allow any enemy in any way to obtain weapons of mass destruction against the people of Israel."

There are critical arguments against a decision to attack a nuclear reactor in an enemy country:

a. Operational risks: The reactors are high value targets that are well protected, and thus an attack incurs the risk of casualties and possible mission failure, which might compound strategic embarrassment with strategic and political costs.

b. Legal risks: The international community opposes preemptive strikes and deems them acts of aggression rather than self-defense. Consequently, international sanctions and punitive measures are possible responses to an attack, and these may result in significant strategic costs.

c. Risk of deterioration into war: The enemy's response might be wide scale and painful - from missile fire and attacks on high value targets in Israel, to all-out war, particularly if there is a common border. ${ }^{3}$

d. Risks of armed non-state actors: As Iran possesses armed non-state internal actors, such as the Iranian Revolutionary Guard, and regional actors such as the Popular Mobilization Forces in Iraq, Hezbollah in Lebanon, the Houthis in Yemen, Hamas and the Islamic Jihad in Gaza, and it possesses military capabilities that can destroy "Israel". So, this paper investigates the "Israeli" risks and apply them on the Iranian case.

This study attempts to understand and analyze the strategic risks that prevent the implementation of the "Israeli" preventive strike against Iranian nuclear facilities. In addition, this study seeks to verify the validity of the hypothesis, which demonstrates that the Islamic Republic of Iran has been able during the past decades to build its peaceful military, political and nuclear

${ }^{1}$ Amos Yadlin, The Begin Doctrine: The Lessons of Osirak and Deir ez-Zor, Institute for National Security Studies, 21/3/2018.

https://www.inss.org.il/he/publication/the-begin-doctrine-the-lessons-of-osirak-and-deir-ezzor /

${ }^{2}$ Doreen Horschig, Is Israel Thinking About a Military Strike on Iran? History Tells Us It's Possible, National Interest, June 24, 2019.

https://nationalinterest.org/blog/buzz/israel-thinking-about-military-strike-iran-history-tellsus-its-possible-63976

${ }^{3}$ Yadlin, The Begin Doctrine. 
power bases, support non-armed state actors, and make them as "barriers" to any possibilities for targeting them militarily at regional and international levels.

\subsection{The Theoretical Framework}

Power or Force is the cornerstone of international relations, especially in its soft and hard forms. Among the many components of power, the military element becomes one of its major characteristics as soon as the State has reached adulthood and come to possess a monopoly of violence. ${ }^{4}$

Here, Iran has worked, from the perspective of this theory, to increase and develop its military capacity in order to avoid military options against its balance. Besides, Israel has found that the use of military force against Iran will destroy its interests, and bring unnecessary damages.

Supporters of the Neo realism school focus on power on the one hand and interest on the other hand, as they consider force as the basic concept in international relations, but there are other relationships that often hide behind moral and legal terms or expressions. ${ }^{5}$

As for classical realists, power is a goal in itself. Although they acknowledge the various elements of power such as economic and technological resources, they demonstrate that military power is the most important component of state power. As for the new realism, it does not agree with those who see military force as an essential tool in running the state. The neo-realists consider power to be more than cumulative in military resources and the ability to use this power to coerce and control other member states of the international system. The neo-realists see force as a collection of the complex capabilities of the state. Consequently, states are differentiated in the system by their power and not by their function. Power gives the state a place in the international system, which in turn determines the state's behavior and its role in international politics. ${ }^{6}$

As for classical realists, power is a goal in itself. Although they acknowledge the various elements of power such as economic and technological resources, they demonstrate that military power is the most important component of state power. As for the new realism, it does not agree with those who see military force as an essential tool in running the state. The neo-realists consider power to be more than cumulative in military resources and the ability to use this power to coerce and control other member states of

\footnotetext{
${ }^{4}$ Shaimaa Owais Abu Eid, Power in International Relations: An Authentic Study, 2018, (Egyptian Institute for Studies) p.1.

${ }^{5}$ Dougherty, J. E. (1971). Contending theories of international relations: A comprehensive survey. Addison Wesley Publishing Company. Pages 8,9,21,24, 82-83.

${ }^{6}$ Ahmed Nuri Al-Naimi. Modern Structuralism in International Relations, Journal of Political Science, No. 46, p.20.
} 
the international system. The neo-realists see force as a collection of the complex capabilities of the state. Consequently, states are differentiated in the system by their power and not by their function. Power gives the state a place in the international system, which in turn determines the state's behavior and its role in international politics. ${ }^{7}$

Therefore, and through the Iranian leadership's understanding of the risks facing its national security since the establishment of its Islamic revolution in 1979, and their understanding of the limits of their military and technological power in light of imposing harsh sanctions on Tehran, they have formulated a relative deterrent force consisting of three pillars, which rest on its ability to (1) threaten navigation through the Strait of Hormuz, (2) undertake terrorist attacks on multiple continents, and (3) conduct long-range strikes, primarily by missiles (or with rockets owned by proxies deployed in many countries of the Middle East such as the Lebanese Hezbollah or the Houthis in Yemen or armed groups in Iraq or some armed Palestinian factions such as the Jihad and Hamas movements, or through cells spread in Europe and Latin America.

\section{2. "Israeli" Strategic Risks of launching a preventive strike against Iran:}

2.1. The Operational Risks: The great and middle powers seek to protect their vital installations and fortify them from any external aggression, so that these sites are built in a special engineering form and in areas far from the population, and they are protected by advanced air defense systems. In the Iranian case, these fortifications make Israel and the United States afraid of failure in any attack against the Iranian nuclear sites, which in turn will lead to strategic and political changes. There is no doubt that Iranian nuclear reactors enjoy a great degree of protection and come in two parts, which are as follows:

The first part relates to advanced air defense systems that protect these vital installations from any foreign air aggression. Iran's S-300s seem to be an amalgam of different generations of Russian air defense systems, reflecting either Tehran's unique operational requirements or patchy availability from Moscow. In any case, Iran is now equipped with a potentially formidable system that can threaten even fifth-generation low-observable aircraft if used properly. The S-300's 64N6E radar can be paired with the 1L119 Nebo electronic beam-steering VHF radar previously delivered by Russia, which could help Iranian operators discriminate between low-observable and conventional radar targets and adjust their response accordingly. Iran also

\footnotetext{
${ }^{7}$ Ahmed Nuri Al-Naimi. Modern Structuralism in International Relations, Journal of Political Science, No. 46, p.20.
} 
bought the sophisticated Avtobaza-M passive surveillance system from Russia in 2011. According to the manufacturer, the mobile Avtobaza can detect lowprobability-of-intercept (LPI) radars associated with stealth aircraft at a range of $150 \mathrm{~km}$. Moreover, the S-300 can operate in "silent mode" with the help of passive systems such as Avtobaza and Kolchuga (also reportedly in Iranian service), which allows it to keep its radar turned off until the end of engagement. $^{8}$

The second part indicates that the construction of nuclear reactors is done in an engineering way to withstand "Israeli" and American missile strikes. Underground nuclear reactors are built 100 meters deep under the rocks and are built with special armed concrete to withstand the large missile attacks.

In 2012 the United States delivered "GBU-28" bunker-busting bombs to "Israel", The GBU-28 is a special bomb developed for penetrating bunkers located deep underground. The GBU-28 can penetrate more than six meters of concrete or more than 30 meters of earth. In addition, the range of this bomb is $9.5 \mathrm{~km}$, and its warhead is $286 \mathrm{~kg} .{ }^{9}$ One or two GBU-28s will be enough to destroy the reinforced dome over the Natanz facility. But the Fordow facility is built inside a mountain at a depth of about 100 meters beneath the rocks. Therefore, all the bombs in service with Israel - GBU-27, GBU-28, GBU-31 are not capable of hitting this object. ${ }^{10}$

The reason for the reluctance of the "Israel" to launch a preventive strike against Iran is due to two main reasons: ${ }^{11}$

The first reason relates to the logistical reasons: Unlike the attack on the Iraqi nuclear reactor (June 1981, "Israeli" strikes will not be as effective due to the dispersion of the sites and the level of protection enjoyed by the Iranian nuclear sites. In addition, given Iran's distance, there will also be technical problems.

The second reason relates to Iran's capabilities to respond by using Shahab-3 missiles, which have a range of 1,300 km, and can reach "Israel". In addition, there is a possibility that Hezbollah will bomb northern Israel and

\footnotetext{
${ }^{8}$ Farzin Nadimi, Iran Takes Another Step Toward Fielding S-300 Missiles, (Washington: washington institute, March 7, 2017).

https://www.washingtoninstitute.org/policy-analysis/view/iran-takes-another-step-toward-

fielding-s-300-missiles

${ }^{9}$ GBU-28 Bunker Buster, Deagel, 2019.

http://www.deagel.com/Defensive-Weapons/GBU-28-Bunker-Buster_a001151007.aspx

${ }^{10}$ Eurasia Daily, Can Iran's nuclear facilities be destroyed in a single strike? The Israeli experience, 7 August 2019.

https://eadaily.com/ru/news/2019/08/07/mozhno-li-unichtozhit-iranskie-yadernye-obektyodnim-udarom-izrailskiy-opyt

${ }^{11}$ Alain Dieckhoff, Directeur de recherche CNRS, Ceri -Sciences Po, vient de publier Le conflit israélo-arabe, Armand Colin, 2011, 182 p.
} 
the rest of the non-Iran-allied actors may carry out some military actions in the region.

There are other reasons that are no less important than the two previous reasons, and they come as follows: ${ }^{12}$

The problem is posed by the wide geographical dispersion of nuclear facilities in Iran over a large area (Isfahan, Arak, Natanz, Bushehr), unlike the Syrian and Iraqi reactors located in one area, which in turn is combined with the insufficient ranges of the "Israeli" aviation. To carry out such an operation, it will be necessary to refuel aircraft - in the air or even at friendly airfields.

Israel realizes that the military option will not stop the Iranian nuclear program, which was confirmed by the former head of the Mossad, Meir Dagan, that it is impossible to contain the Iranian nuclear program, and waving a military option - it does not deter the Iranians, but serves their interests, and will not prevent Iran from having nuclear weapons. He added that There are other alternatives to address the Iranian challenge. He also indicated that the military option against Tehran could completely backfire, such as accelerating the pace of the Iranian nuclear program, solidify the Iranian people, who are currently divided and partly disgusted by the regime. ${ }^{13}$

2.2. The Legal Risks: Since its occupation of the Palestinian lands in 1948, Israel has adopted the doctrine of "preventive war", which was later called the "Begin Doctrine,". It was also the first application of a process after its 1967 military attack on Jordan, Egypt and Lebanon, and renewed that after its attack on Palestinian refugee camps in Lebanon In 1975, the Tammuz nuclear reactor in Iraq in 1981, as well as the Syrian nuclear reactor in Deir Ez-Zor in 2007. Israel justified all its military attacks by what it called "preventive legitimate defense" at that time.

Article 51 of the United Nations Charter states that: "Nothing in the present Charter shall impair the inherent right of individual or collective selfdefense if an armed attack occurs against a Member of the United Nations, until the Security Council has taken measures necessary to maintain international peace and security. Measures taken by Members in the exercise of this right of self-defense shall be immediately reported to the Security Council and shall not in any way affect the authority and responsibility of the Security Council under the present Charter to take at any time such action as it deems necessary in order to maintain or restore international peace and security. ${ }^{14}$

12 Abdullah Al-Rashdan, Al-Khammash Rana, The Iranian Nuclear Program, Regional and International Dimensions 2002-2016, (Naif University Publishing House, 2017), 113-114.

${ }^{13}$ Website walla, Meir Dagan: "An attack will not stop Iran's nuclear program".2012 https://news.walla.co.il/item/2537658

${ }^{14}$ Charter of the United Nations, 32-33. 
Ismail Sabri defines the preventive war as the main aspect of planning a nuclear strategy on the basis of pure attack, as a particular party seeks to embrace this strategy that ensures the maximum possible damage to the opponent, and this is considered the best alternative to the defensive strategy. While Samuel Huntington defines it as a purely military action carried out by one country against another, with the aim of preventing a change in the balance of power between the two states, which leads to a reduction in the military security of the first country. ${ }^{15}$ The preventive war here aims to prevent the shifting of balance of power, such as those aimed at stopping the enemy from obtaining the means that enhance its strategic position.

Preventive war means the state's right to take preemptive military action to prevent imminent military aggression. Article 51 of the United Nations Charter has been the controversial among legal scholars and politicians regarding its interpretation. It states: Nothing in the present Charter shall impair the inherent right of individual or collective self-defense if an armed attack occurs against a Member of the United Nations, until the Security Council has taken measures necessary to maintain international peace and security. Measures taken by Members in the exercise of this right of selfdefense shall be immediately reported to the Security Council and shall not in any way affect the authority and responsibility of the Security Council under the present Charter to take at any time such action as it deems necessary in order to maintain or restore international peace and security. ${ }^{16}$

The interpreters differed on this Article (51) and divided into two directions: the first expanded its interpretation, and the second added to its interpretation: ${ }^{17}$

The first trend: among them is "Bowett", who believes in expanding the interpretation of Article 51 to protect the state and preserve its existence, especially in light of the tremendous development in weapons, which may expose the state to a fatal blow that paralyzes its defenses and threatens its existence. This interpretation is based on the principle of surprising the enemy before being surprised.

The second trend indicates that the right to legitimate self-defense is in the case of an armed aggression against the state. As for saying that there is an imminent danger, it is not sufficient to be a justification for a legitimate selfdefense, and this is a restriction on the exercise of the right to legitimate selfdefense except in one case, which is a case of aggression, and most of the jurists support this trend. Legitimate self-defense should be practiced only in case of armed attack.

${ }^{15}$ Ben Ammar Imam, Preventive War in American Strategic Thought - Iraq as a Case Study

- (Algeria: University of Muhammad Khudair - Biskra, 2008), p. 17.

${ }^{16}$ Makhadmeh, Preventive War, 383.

${ }^{17}$ Ibid, p. 383-384. 
By looking at Article (51), there are conditions for legitimate self-defense, which are: 18

1. The occurrence of an armed aggression against the state.

2. The proportionality between the defense and the act of assault.

3. Notify the UN Security Council: Article 51 of the United Nations Charter stipulates that the state that responds to aggression shall notify the Security Council of the measures it has taken to defend itself.

3.3. Military Risks: The Islamic Republic has diversified and wellqualified military capabilities in its military, land, sea, air and defense sectors, and has proven its efficiency in a limited range of the recent confrontation in the Gulf, especially after shooting down the American spy plane.

Iranian engineers and scientists are adept at developing cutting edge military technologies. It has been ten years, for example, since Iran successfully launched its first satellite into orbit. Of course, satellite launch technology can provide cover for advanced ballistic missile work. Tehran is seeking, through massive updates in military industrialization, to change the regional military balance in its favor. ${ }^{19}$

The Iranian government has also encouraged nanotechnology investment. It has created joint nanotech centers in China and active links between Iranian and Chinese nanotech companies. However, it acquires technology, Iranian military tacticians increasingly appear to be incorporating artificial intelligence if not fully autonomous systems into their platforms. As the Iranian leadership embraces new technologies, its whole-of-government approach means that its work occurs not only on military bases, but also in Iran's universities and nominally civilian companies within the Islamic Revolutionary Guard Corps' economic empire. Indeed, one of the primary motives for the Islamic Republic to send students - especially the children of regime elites and other loyalists - to Western universities and to invest heavily in cyber-espionage is to gain access to the latest in advanced technical fields. ${ }^{20}$

\subsubsection{Iranian ballistic missiles:}

Iran's ballistic missiles constitute a primary component of its strategic deterrent. Lacking a modern air force, Iran has embraced ballistic missiles as a long-range strike capability to dissuade its adversaries in the regionparticularly the United States, Israel, and Saudi Arabia—from attacking Iran.

\footnotetext{
${ }^{18}$ Makhadmeh, Preventive War, 385-386.

${ }^{19}$ Michael Rubin, Iran's Military Is Making Strides into Twenty-First Century Technology, national interest, August 8, 2019.

https://nationalinterest.org/blog/middle-east-watch/irans-military-making-strides-twentyfirst-century-technology-72191

${ }^{20}$ Ibid.
} 
Iran has the largest missile force in the Middle East, with a substantial inventory of close-range ballistic missiles (CRBMs), short-range ballistic missiles (SRBMs), and medium-range ballistic missiles (MRBMs) that can strike targets throughout the region as far as 2,000 kilometers from Iran's borders. Iran is also developing land-attack cruise missiles (LACMs), which present a unique threat profile from ballistic missiles because they can fly at low altitude and attack a target from multiple directions. Iran is also working to develop many ballistic missiles with high accuracy, such as the "Emad-1" missile, that improve Iran's ability to strike distant targets more effectively. Iran could also complicate regional missile defenses by launching large missile salvos. ${ }^{21}$

Iran uses a number of strategic tools for regional hegemony instead of comprehensive military techniques in the Air Force and Navy, which suffer from great weakness as a result of the international embargo imposed on Iran from importing weapons and spare parts for its various sectors of war. These strategic tools can be summed up in two main axes, the first: building a missile base Large and wide-ranging that would grant immunity to the Iranian political system, allow Iran to pose strategic threats to its enemies in the Middle East, and create a balance of deterrence to prevent any possible attack on its vital installations. The second: Building and supporting armed non-state actors, namely the armed groups in Iraq, Syria, Lebanon and the Gaza Strip, which will be a deterrent to any aggression against Iran. ${ }^{22}$

A key component of Iran's military doctrine is the development of an indigenous ballistic missile program, and the country's rapid development of missile expertise has raised concerns in the US and among its allies. Iran embarked on an indigenous ballistic missile program in 1986, when the Revolutionary Guards created a "self-sufficiency unit" to develop military industries that would not require assistance from other countries. ${ }^{23}$

Iran has the largest and most diverse ballistic missile arsenal in the Middle East. (Israel has more capable ballistic missiles, but fewer in number and type.) Most were acquired from foreign sources, notably North Korea. The Islamic Republic is the only country to develop a 2,000-km missile without first having a nuclear weapons capability. Iran is still dependent on foreign suppliers for some key ingredients, components and equipment, but it has the technical and industrial capacity to develop long-range missiles, including an Intercontinental Ballistic Missile, or ICBM. ${ }^{24}$

\footnotetext{
${ }^{21}$ Anthony H. Cordesman, Iran and the Changing Military Balance in the Gulf - Net Assessment Indicators, Center for Strategic and International Studies, page.197

${ }^{22}$ Shaul Shi ،Iranian Missile Strategy ،(IDC Herzliya: Herzliya ،9.2018) rpage 1-2.

${ }^{23}$ Farhad Rezaei, Iran's Ballistic Missile Program: New Developments, BESA Center Perspectives Paper No. 1,110, March 12, 2019, page 1.

${ }^{24}$ Michael Elleman, Iran's Ballistic Missile Program, United states institute of peace.
} 
Iran has come a long way in building the largest missile system in the Middle East, and thus it has the largest firepower in the region, and it is the most important tool today for deterrence and therefore it strongly refuses to discuss imposing restrictions on it. During recent years, it has sought to improve the quality of missiles, expand their range and improve their accuracy, which imposes a safe space for the Iranian regime. ${ }^{25}$

Since the signing of the $5+1$ Vienna Agreement, Iran has conducted a series of tests of medium-range ballistic missiles, satellite launchers and cruise missiles. Al-Awsat believes that the international, regional, and even commanders of senior generals in the Iranian army have stated that Iran has the ability to launch a large number of missiles against its opponents, which is the most important element in deterrence and the ability to defend itself, at least as long as it does not possess nuclear weapons. ${ }^{26}$

\section{Iranian missiles can be classified into two main categories: ${ }^{27}$}

- The long-range strategic ballistic missile group, which could strike strategic targets in Israel, Saudi Arabia and US bases throughout the Middle East. In the future, this system aims to carry nuclear warheads when Iran is allowed to develop them.

- Short and medium-range missiles, which Iran supplies to armed nonstate actors in the vicinity of its regional opponents such as Hezbollah, Hamas, Jihad, Shiite groups in Syria and Iraq, and the Houthis in Yemen.

\subsubsection{Air defense systems}

Iran possesses many advanced air defense systems, which have proven their presence in the operational and field, such as the "Nazir" and "Pina" system, which are considered as two air defense systems that have the ability to strike long-range targets, as well as fight in light of electronic wars. Also, Iran has multiple radar systems, with different ranges and functions. Some of them are coastal and some ship-borne radar, and their ranges are $60-500 \mathrm{~km}^{28}$

This is what happened recently after Russia signed a memorandum of understanding with Tehran to start supplying the advanced "S-300" system after years of delay. This system has a range of $400 \mathrm{~km}$, and it can target 100 targets in the region at one time and engage 12 other targets at the same time. It can also target infiltrating secret aircraft and ballistic missiles, and this

\footnotetext{
${ }^{25}$ Ephraim Kam, Iran's Missile System: The Principal Means of Deterrence, (Institute for National Security Studies: Tel Aviv (22.4.2019), p 2.

${ }^{26}$ Ibid, p. 7-8.

${ }^{27}$ Ibid, $1-2$.

${ }^{28}$ Commander Joshua Himes, "IRAN'S TWO NAVY: A MATURING MARITIME

STRATEGY", The Institute for the Study of War (US), October 2011, Pages 6, 8, and 17.
} 
missile defense system will enable Iran to fortify its nuclear sites from any military attack on them. It would also change the standards regarding nuclear negotiations between Iran and the major powers. ${ }^{29}$

Iran also revealed another modern system, "Khordad 15", which can detect targets such as fighters and drones attacking $150 \mathrm{~km}$ away and track targets at $120 \mathrm{~km}$. It is able to detect hidden targets at a distance of $85 \mathrm{~km}$ and engage with and destroy them at a distance of $45 \mathrm{~km}$. It is also able to detect and track 6 targets simultaneously, carry out, launch and destroy operations against 6 targets. In addition to its ability to engage targets at an altitude between $27-150 \mathrm{~km}$ and a range of 7 to $75 \mathrm{~km}$ ). ${ }^{30}$

On August 10, 2019, Iran revealed an advanced missile defense system with a combat range of up to $400 \mathrm{~km}$. This system is equipped with a "gamma" or "falaq" radar, and the system is able to detect types of cruise missiles, ballistic missiles, stealth aircraft, drones, and others. ${ }^{31}$

Falaq's radar is considered an analogue of the Russian "Gamma-DE" radar. This radar can monitor 200 DFMs and update its data every 5 seconds, ${ }^{32}$ while Falaq's radar has great capabilities. It is able to detect and track targets that move at high speed and at an altitude of 5 meters $-120 \mathrm{~km} .{ }^{33}$

In the first operational tests and in completely realistic conditions, the Iranian home-made air and missile defense system proved to be of tremendous capabilities when it managed to shoot down the most advanced American spy plane in the US Navy (RQ-4A Global Hawk), which in turn represents a serious challenge to military superiority of the USA in the air. ${ }^{34}$

With all these defensive capabilities, the US military magazine "The National Interest" argues, Iran poses a major challenge to US F-22s, even though American aircraft and Russian S-300 defense systems have never formally encountered. And if Iran acquires the Russian "S-400" system, almost everything will change. Recently, the Russian ambassador to Iran

\footnotetext{
${ }^{29}$ Maysam Behravesh, "Will Russia Live Up to Its Iran S-300 Contract?", CBS News, October 5, 2015, Page 1

${ }^{30}$ The Islamic Republic News Agency (IRNA), the unveiling of a new Iranian air defense system, June 9, 2019.

https://2u.pw/Xudh9

${ }^{31}$ Reuters Agency, Iran unveils an upgraded missile defense system, 10/8/2019. https://ara.reuters.com/article/topNews/idARAKCN1V008Z

${ }^{32}$ Website Rosoboronexport, AIR DEFENCE SYSTEMS.

http://roe.ru/eng/catalog/air-defence-systems/radar-and-electro-optical-equipment-for-airtarget-detection/gamma-de/

${ }^{33}$ Website actualnews, The Ability of the Iranian super-radar "Falagh" will undermine the competitiveness of the American aircraft electronic warfare "Growler", 15.08.2019. https://actualnews.org/exclusive/304206-potencial-iranskoj-super-rls-falagh-podorvetkonkurentosposobnost-amerikanskogo-samoleta-rjeb-grouler.html ${ }^{34}$ global security, 'Iran has sent a message!' Experts on downing of US drone, Jun 25, 2019. https://www.globalsecurity.org/wmd/library/news/iran/2019/iran-190625-presstv06.htm
} 
announced that his country will not face a problem in selling Tehran the advanced air and missile defense system "S-400" when the arms embargo imposed by the United Nations on the Islamic Republic ends. ${ }^{35}$

The real danger with upgraded S-400s, it would appear, likely pertains to computer processing speeds the extent to which they are networked to one another. If an ability to maintain a "track" on an aircraft improves at higher speeds over greater ranges due to an ability to more quickly integrate and network information than planes could be more vulnerable even if the hardware or munitions themselves have not changed much.

\subsubsection{The Navy:}

The Iranian Navy relies on speed and camouflage in order to carry out effective attacks, so hundreds of small boats and ships have been equipped with a wide range of simple weapons, ranging from machine guns to missile launchers and short-range missiles such as the 704-C and Nasr-1 missiles, and torpedoes such as an Iranian-made torpedo (whale), in addition to reconnaissance and intelligence drones. The Iranian navy possesses ballistic missiles capable of disabling US aircraft carriers, such as the Fateh-110 missiles. ${ }^{36}$

Iran recently developed an anti-ship missile "Zulfiqar Naseer", which has a range of $700 \mathrm{~km}$. This type of Iranian missile has a great ability to carry out accurate strikes against naval targets in the Strait of Hormuz region. Of course, the biggest feature of this anti-ship missile is the photoelectric researcher, and it is a major achievement in the Iranian missile technology. This missile can also counteract interference, making it relatively perfect in all respects. Therefore, this missile poses a great threat to US aircraft carriers, which may become a living target. ${ }^{37}$

While Iran has an integrated mix of naval forces, it has three classes of kilo submarines that it took from Russia in the 1990s, and it has built a number of submarines, these submarines fire long-range lethal torpedoes and can plant mines. It had a Ghader missile weighing 120-150 tons in 2007. Now it has 17 types. Each submarine carries a mixture of 18 missiles and guided torpedoes,

\footnotetext{
${ }^{35}$ Kris Osborn, Could Iran Shoot Down a U.S. F-22, F-35 or Stealth B-2 Bomber? The National Interest Magazine, October 9, 2020.

https://nationalinterest.org/blog/buzz/could-iran-shoot-down-us-f-22-f-35-or-stealth-b-2bomber- 170417

${ }^{36}$ Eyal Pinko, Dealing with lateral assumptions in an asymmetrical naval campaign; The Revolutionary Guards Navy in Iran as a case study, Haifa University, January 2017, p 7984.

${ }^{37}$ Sina newspaper, The third anti-ship missile appeared suddenly, with a range up to 700 $\mathrm{km}$, and the U.S. aircraft carrier will become an open target, 17/10/2020.

https://k.sina.com.cn/article_6433466398_17f76e81e00100sg4s.html?cre=tianyi\&mod=pcpa ger_news \&loc $=3 \& \mathrm{r}=9 \& \mathrm{rfunc}=34 \& \mathrm{t} \mathrm{j}=$ none $\& \mathrm{tr}=9$
} 
and Iran has purchased 1,000 modern Russian mines. These mines are equipped with modern and accurate sensors that these submarines can hit torpedoes for a distance of 4000-6000 meters to hit targets that no country can reach or discover. Iran also has huge numbers of anti-ship missiles on different types of launch pads in addition to advanced naval aviation used for maneuvering. ${ }^{38}$

\subsubsection{Air Force}

The Iranian air force on paper is one of the biggest air arms in the world. Its order of battle includes around 350 fighters, more than twice as many as the Royal Air Force possesses.

But most of Iran's fighters are old and outdated. The ones that aren't old are just new copies of old designs. The air force's squadrons fly Americanmade F-14s, F-5s and F-4s dating from the 1970s, some 1980s-vintage MiG29s and Sukhoi fighter-bombers and a few J-7s that the Islamic Republic bought from China during the 1990s. Tehran tried again, ordering from a cashhungry Russia a fresh batch of bombers. This time around the United States successfully applied pressure on Russia to cancel the sale. ${ }^{39}$

\subsection{Armed non-state Actors:}

The Islamic Republic of Iran has deliberately built and supported a large and extended base of armed non-state actors in areas adjacent to its regional enemies or opponents, which is an old Iranian strategy to preserve its national security from any "Israeli" or Western aggression, as it feels that it is being targeted by Israel and the West for its nuclear ambition and regional hegemony.

One of the most important non-state actors formed by the Islamic Republic of Iran is the "Iranian Revolutionary Guard", an organization independent of the armed forces organizations. The Revolutionary Guard's total is 125,000 individuals, divided in the country into the sectors of the Navy, Marine Corps and Air Force, and the Revolutionary Guard represents nearly a quarter of the total. Iran's regular military forces are equivalent to (24\%) of the total armed forces. ${ }^{40}$

\footnotetext{
${ }^{38}$ The previous reference, Page 25- 31.

${ }^{39}$ David Axe, Iran Has A Big Air Force, But One Reason Keeps It Weak, The National Interest Magazine, December 9, 2019.

https://nationalinterest.org/blog/buzz/iran-has-big-air-force-one-reason-keeps-it-weak103457

${ }^{40}$ A previous reference, Page 10.
} 


\subsection{The strategic consequences of ending the arms embargo on Iran:}

After the end of the arms embargo on Iran on October 18, 2020, imposed by the United Nations within the " $5+1$ " nuclear agreement, officially known as the "Joint Comprehensive Plan of Action", Tehran can import and export all kinds of heavy conventional military equipment. Although the United States tried many times to extend the arms embargo in various ways, all of these attempts were unsuccessful.

On the other hand, Iran will seek to purchase military equipment and obtain a license to produce it domestically, such as the basic components of modern combat aircraft. Iran will not have a chance to enhance its military capabilities unless it is able to become self-sufficient in the production of these weapons in the future. For many decades, US sanctions on Iran caused huge financial losses. It is likely that the strength of the Iranian military will gradually recover, yet the United States will continue to obstruct Iranian efforts from time to time, and how to deal with the American effort depends solely on Iran's behavior. ${ }^{41}$

Iran has recently been able, through its domestic defense investments, to acquire some unique capabilities, which have enabled it to deliver longrange precision strikes, wage guerrilla warfare, and conduct proxy operations. The regime used these capabilities to extend its regional influence and protect its internal area from any external aggression. ${ }^{42}$

In Tehran's view, the successes that its proxies and partners have registered in the Middle East - expelling "Israeli" forces from Lebanon in 2000, ousting U.S. forces from Iraq in 2011, and defeating the "U.S.-SaudiZionist conspiracy" to unseat Bashar al-Assad in Syria since 2011-have vindicated its approach of using force to shape the regional security environment. Iran also regards its armed forces as an effective deterrent against a large conventional attack - a mindset no doubt reinforced by Washington's reluctance to employ military levers as an integral part of its maximum pressure policy. Iran is therefore likely to maintain this basic approach if the ban on arms transfers ends later this year, while filling capability gaps and selectively modernizing its conventional forces to reflect lessons learned in Syria. To this end, it would try to purchase at least some of the systems it has been unable to produce domestically, such as advanced

\footnotetext{
${ }^{41}$ Sina newspaper, All obstacles failed, and the iranian arms embargo was lifted gradually! Russian experts analyze the weapons that iran will purchase, 21/10/2020. https://k.sina.com.cn/article_7451666431_1bc2767ff00100wgc3.html?cre=tianyi\&mod=pcp ager_news\&loc $=7 \& \mathrm{r}=9 \& \mathrm{rfunc}=34 \& \mathrm{tj}=$ none $\& \operatorname{tr}=9$

${ }^{42}$ Michael Eisenstadt, If the Arms Ban Ends: Implications for Iran's Military Capabilities, The Washington Institute, July 23, 2020. https://www.washingtoninstitute.org/policy-analysis/view/if-the-arms-ban-endsimplications-for-irans-military-capabilities
} 
surface-to-air missiles (SAMs), fighter aircraft, infantry fighting vehicles, and tanks. ${ }^{43}$

It is likely that any process of purchasing new weapons will be for defensive or deterrent purposes and will be viewed by the Iranians as a policy against any possible attack on Iran by its opponents. On the other hand, lifting the arms embargo may not have a significant impact on Iran's imports. It is likely that Iran will become a major regional supplier of military equipment through its exports. Iran would benefit from selling its domestically produced weapons and other military equipment at a much lower price than other countries can offer. Syria is likely to be the first country to be interested in importing Iranian defense systems, especially after the two countries signed a defense agreement to strengthen bilateral military cooperation. ${ }^{44}$

Iran's primary goal in benefiting from the lifting of the arms embargo will be to address the weaknesses in its vital military sectors, such as the air force, submarines and warships, and develop its advanced capabilities in the air defense force. It is also likely that Iran will import advanced weapons from Russia and China with permission to produce them domestically through selfefforts, and this scenario is closest and appropriate to the Iranian economic reality.

\section{Expected Losses of Wider War with Iran address all the military scenarios}

Before addressing the expected losses of the attacking parties, "Israel" as a first party and the United States as a secondary party, there are three broad forms that military action could take: a directed strike against Iranian nuclear facilities, a larger strike that included general military targets, or a full-scale invasion with the intent to overthrow the Iranian regime. ${ }^{45}$

The latter two scenarios are probably not realistic options for Israel to reduce the level of the Iranian nuclear threat, and Israel cannot work to achieve it alone, even with its strategic ally, which is America, since the latter has not yet recovered from the nightmare of Afghanistan and Iraq and has not completely healed from the global economic crisis that occurred in 2008.

In addition, there is a major problem with Washington and Tel Aviv, as the military operation against Iran will practically require more than just a series of attacks on a small area, but the attacking countries will need to expand

\footnotetext{
${ }^{43}$ Ibid.

${ }^{44}$ Farhad Rezaei, The strategic consequences of ending the arms embargo on Iran, The Bulletin, August 14, 2020.

https://thebulletin.org/2020/08/the-strategic-consequences-of-ending-the-arms-embargo-oniran/

${ }^{45}$ Whitney Raas and Austin Long, Osirak Redux?: Assessing Israeli Capabilities to Destroy Iranian Nuclear Facilities, (The MIT Press: USA)Vol. 31, No. 4 (Spring, 2007), pp. 9.
} 
the fire circle to a large area beyond and target the main army and Iranian Revolutionary Guard headquarters during the first day of the military operations. Washington and Tel Aviv are obliged to target the main sites of non-state actors associated with Iran in various countries in the Middle East. ${ }^{46}$ Also, talking about the war scenario between Washington and Tel Aviv on the one hand and Tehran on the other hand is not inevitable, but it is likely to happen in light of the increasing tension between those parties, but the most important question that is on the minds of observers and those interested in Middle East affairs, what are the costs of this war on Washington, Israel and its regional allies?

On the other hand, apprehension and appreciation of the expected losses from any war on Iran increases the fears of the United States and Israel, as these losses are always present in the strategic, military and security minds of both sides.

The Islamic Republic of Iran possesses various weapons that have the ability to target all American military bases stationed in many countries of the Middle East, and Tehran also has the ability to target US military naval vessels located in the Arabian Gulf, which is agreed upon by many experts, as the Russian military expert Konstantin expects Sevkov: "Tehran has enough weapons in its arsenal to inflict serious losses on the United States. ${ }^{47}$

The expert Sivkov estimates that the American losses will be from the early hours of the start of the war, in which the US army could lose hundreds of its soldiers, and that the Iranian armed forces could direct missile strikes to the enemy forces and destroy $10-15 \%$ of the military aircraft stationed in the Gulf. $^{48}$

More broadly, the regional scene will carry many retaliatory responses and will not stop at Tehran alone. Rather, retaliatory responses will start from Iran, whether by the regular army or the Revolutionary Guard through secondary bases or through a backup plan developed by the Iranian military and political leadership, and at this time the first retaliatory responses will begin. The core of Iranian targets will then contain vital targets for the Gulf countries, including the US military bases and oil installations, in addition to targeting oil and military ships along the Gulf Sea and the Strait of Hormuz, and non-state actors associated with Iran will participate in the retaliatory operations, such as the Houthi group in Yemen, the Popular Mobilization Forces in Iraq and groups, The armed forces in Syria, Hezbollah in Lebanon and the resistance factions in Gaza. At that time, the space for retaliatory

\footnotetext{
${ }^{46}$ Rogers Paul, "Iran: Consequences of the outbreak of war," Journal of Middle Eastern Studies, Vol. 11, pp. 37.36, (2006), 198-201.

${ }^{47}$ Website avia.pro, First US losses in the war with Iran announced, 23/5/2019.

http://avia.pro/news/ozvucheny-pervye-poteri-ssha-v-voyne-s-iranom

${ }^{48}$ Ibid.
} 
responses will extend to Israel and US military bases in all countries of the Middle East. ${ }^{49}$

\section{Conclusion}

Tehran's large and diverse regular military force or its military allies in the Middle East prevents Israel from any unilateral military action, and makes the joint military action between Washington and Tel Aviv today heavy and risky, but war decision could overcome all these expected dangers and start with accurate and wide military operations, which will put the regional and international arenas on the edge of wars, which can only be stopped by invading one party, which is something that absolutely cannot be rushed!

Obviously, in the Iranian case, the preventive war cannot be stopped at the borders of the first military operations in striking Iranian nuclear sites and military sites for the Iranian army and the Iranian Revolutionary Guards. Non-state actors will conduct military actions and attack "Israel" and the interests of the United States in the Middle East as a whole.

In other cases, the war against Iran and its non-state actors is bound to be a strategic threat to the security of "Israel" and the interests of the United States in the Middle East. Washington and Tel Aviv could have finished off Tehran at the beginning of the Iranian nuclear file in 2003, but it lost this opportunity today due to the development of the extended Iranian military force in Iraq, Syria, Lebanon and Yemen to the Gaza Strip. "Israel" is also aware that delaying the war is more harmful to its power.

In other words, the United States and "Israel" are well aware of the risks and losses that are expected to pay if they launch a war against Iran, and therefore it is expected that both countries will refrain from targeting Iran because of the great security risks related to that decision. So, the scene will return to the beginning of searching for a peaceful way out of the crisis, which in turn guarantees the West and Israel to limit the risks attributed to Iran and its alliance in the region, and on the other hand, guarantees Iran its national rights.

Likewise, Iran will not accept the American and international sanctions imposed on it, which will escalate tension in the region and raise the ceiling of expectations and risks related to the outbreak of a comprehensive or limited war between the various parties. Therefore, there is no way out for the United States, the West and "Israel" to come out of the crisis except through the official declaration of Iran, its full national rights and regional sovereignty, and a return to the "Vienna $5+1$ " agreement.

On the other hand, if we resolve the debate over assessing the ability of "Israel" to destroy the Iranian nuclear facilities, especially after the

\footnotetext{
${ }^{49}$ Paul, "Iran: Consequences of the outbreak of war, 2003-207.
} 
modernization that accompanied its air force and firepower that might enable it to destroy nuclear facilities. The desired benefit of a military operation is to prevent Iran from developing a nuclear weapon. A very important question is raised here, which is: Is this benefit worth the operational risks and the political and military costs?

So after the end of all the circumstances before Israel realizes Begin's preventive doctrine in the Iranian scene, nothing remains in front of it except what the former Mossad chief, Meir Dagan said, regarding the continuation of the shadow war with Iran in an effort to delay the maturation of the nuclear program at a time when stopping it is impossible and fraught with very great risks for the "Israeli" national security.

\section{References:}

1. Abu Eid Owais Shaimaa, Power in International Relations: An Authentic Study, 2018, (Egyptian Institute for Studies) p.1.

2. Al-Rashdan Abdullah, Al-Khammash Rana, The Iranian Nuclear Program, Regional and International Dimensions 2002-2016, (Naif University Publishing House, 2017), 113-114.

3. Al-Naimi Nuri Ahmed. Modern Structuralism in International Relations, Journal of Political Science, No. 46, p.20.

4. Imam Ben Ammar, Preventive War in American Strategic Thought Iraq as a Case Study - (Algeria: University of Muhammad Khudair Biskra, 2008), p. 17.

5. Paul Rogers, "Iran: Consequences of the outbreak of war," Journal of Middle Eastern Studies, Vol. 11, pp. 37.36, (2006), 198-201.

6. Saadi Muhammad, Between Preventive War and Preemptive War in Public International Law, Ahmed Zabana University Center in Baghlizan - Institute of Legal and Administrative Sciences, No. 1, (2010).

7. Muqatil al sahra encyclopedia.

8. http://www.moqatel.com/openshare/Behoth/Siasia21/TawazonKiw/in dex.htm

9. The Islamic Republic News Agency (IRNA), the unveiling of a new Iranian air defense system, June 9, 2019. https://2u.pw/Xudh9

10. Islamic Republic News Agency "IRNA", Commander of the Iranian Land Forces: Our Armed Forces are invincible, 10/8/2019. https://2u.pw/IXbRg

11. Reuters Agency, Iran unveils an upgraded missile defense system, $10 / 8 / 2019$. https://ara.reuters.com/article/topNews/idARAKCN1V008Z

12. Yadlin Amos, The Begin Doctrine: The Lessons of Osirak and Deir ez-Zor, Institute for National Security Studies, 21/3/2018. 
13. Shi Shaul 'Iranian Missile Strategy ‘(IDC Herzliya: Herzliya ‘ 9.2018).

14. Kam Ephraim, Iran's Missile System: The Principal Means of Deterrence, (Institute for National Security Studies: Tel Aviv ، 22.4.2019).

15. Pinko Eyal, Dealing with lateral assumptions in an asymmetrical naval campaign; The Revolutionary Guards Navy in Iran as a case study, Haifa University, January 2017, p 79-84.

16. Spyer Jonathan, Berman Lazar, The Rise of Iraq's Shia Militias: An Emergent Threat to Israel, Institute for National Security Studies, 20.02.2019. https://jiss.org.il/en/spyer-berman-the-rise-of-iraqs-shiamilitias-and-their-threat-to-israel/

17. Meir Dagan: "An attack will not stop Iran's nuclear program" Website walla, 2012.

18. https://news.walla.co.il/item/2537658

19. Behravesh Maysam, "Will Russia Live Up to Its Iran S-300 Contract?", CBS News, October 5, 2015, Page 1.

20. Cordesman, Anthony H: IRAN'S ENDURING MISSILE THREAT: THE IMPACT OF NUCLEAR AND PRECISION GUIDED WARHEADS, Center for Strategic and International Studies (CSIS): June 10, 2015.

21. Cordesman H. Anthony, "The Gulf Military Balance- Volume II: The missiles and Nuclear Dimensions", January 2014, Center for Strategic and International Studies (CSIS), Page 28.

22. Claire Taylor, "Iran: Conventional Military Capabilities", International Affairs and Defense Section, 24 September 2009, Page 6.

23. Design Characteristics of Iran's Ballistic and Cruise Missiles", Nuclear Threat Initiative, January 2013, Page 1-3.

24. Dieckhoff Alain, Directeur de recherche CNRS, Ceri-Sciences Po, vient de publier Le conflit israélo-arabe, Armand Colin, 2011, 182 p.

25. E. J. Dougherty (1971). Contending theories of international relations: A comprehensive survey. Addison Wesley Publishing Company. Pages 8,9,21,24, 82-83.

26. Elleman Michael, Iran's Ballistic Missile Program, United states institute of peace.

27. H. Cordesman Anthony, Iran and the Changing Military Balance in the Gulf - Net Assessment Indicators, Center for Strategic and International Studies, page 197.

28. Himes Joshua Commander, "IRAN'S TWO NAVY: A MATURING MARITIME STRATEGY", The Institute for the Study of War (US), October 2011, Pages 6, 8, and 17. 
29. Raas Whitney and Long Austin, Osirak Redux?: Assessing Israeli Capabilities to Destroy Iranian Nuclear Facilities, (The MIT Press: USA)Vol. 31, No. 4 (Spring, 2007), pp. 9.

30. Raimzhanova Aigerim. (2015). POWER INIR: HARD, SOFT, AND SMART. Institute for Cultural Diplomacy and the University of Bucharest. Pages 3-5.

31. Rezaei Farhad, Iran's Ballistic Missile Program: New Developments, BESA Center Perspectives Paper No. 1,110, March 12, 2019, page 1.

32. Secretary of Defense, "Unclassified Report on Military Power of Iran", April 2010, Page 1-12.

33. Axe David, Iran Has A Big Air Force, But One Reason Keeps It Weak, The National Interest Magazine, December 9, 2019.

34. https://n9.cl/rcvuw

35. Axe David, "Iran Winning the Underground Arms Race", The Daily Beast, 16 October 2015, Page 1.

36. https://n9.cl/5xspg

37. Eisenstadt Michael, If the Arms Ban Ends: Implications for Iran's Military Capabilities, The Washington Institute, July 23, 2020.

38. https://n9.cl/r9pm9

39. GBU-28 Bunker Buster, Deagel, 2019.

40. https://n9.cl/aa2f

41. Global security, Army / Islamic Iranian Ground Forces (IIGF).

42. https://www.globalsecurity.org/military/world/iran/army.htm

43. global security, 'Iran has sent a message!' Experts on downing of US drone, Jun 25, 2019.

44. https://www.globalsecurity.org/wmd/library/news/iran/2019/iran190625-presstv06.htm

45. Horschig Doreen, Is Israel Thinking About a Military Strike on Iran? History Tells Us It's Possible, the National Interest, June 24, 2019.

46. https://nationalinterest.org/blog/buzz/israel-thinking-about-militarystrike-iran-history-tells-us-its-possible-63976

47. Hume Tim, Iran test-fires new generation long-range ballistic missiles, CNN: October 12, 2015 Page1.

48. http://edition.cnn.com/2015/10/11/middleeast/iran-ballistic-missiletest/

49. Nadimi Farzin, Iran Takes Another Step Toward Fielding S-300 Missiles, (Washington: washington institute, March 7, 2017).

50. https://www.washingtoninstitute.org/policy-analysis/view/iran-takesanother-step-toward-fielding-s-300-missiles

51. Osborn Kris, Could Iran Shoot Down a U.S. F-22, F-35 or Stealth B-2 Bomber? The National Interest Magazine, October 9, 2020. 
52. https://nationalinterest.org/blog/buzz/could-iran-shoot-down-us-f-22f-35-or-stealth-b-2-bomber-170417

53. Rezaei Farhad, The strategic consequences of ending the arms embargo on Iran, The Bulletin, August 14, 2020.

54. https://thebulletin.org/2020/08/the-strategic-consequences-of-endingthe-arms-embargo-on-iran/

55. Rosoboronexport, AIR DEFENCE SYSTEMS.

56. http://roe.ru/eng/catalog/air-defence-systems/radar-and-electrooptical-equipment-for-air-target-detection/gamma-de/

57. Rubin Michael, Iran's Military Is Making Strides into Twenty-First Century Technology, national interest, August 8, 2019.

58. https://nationalinterest.org/blog/middle-east-watch/irans-militarymaking-strides-twenty-first-century-technology-72191

59. Writer Staff, "Iran Military Strength", Global Firepower, 13 November 2015.

60. http://www.globalfirepower.com/country-military-strengthdetail.asp?country_id=iran

61. Website avia.pro, First US losses in the war with Iran announced, 23/5/2019.

62. http://avia.pro/news/ozvucheny-pervye-poteri-ssha-v-voyne-s-iranom

63. Website actualnews, The Ability of the Iranian super-radar "Falagh" will undermine the competitiveness of the American aircraft electronic warfare "Growler", 15.08.2019.

64. https://actualnews.org/exclusive/304206-potencial-iranskoj-super-rlsfalagh-podorvet-konkurentosposobnost-amerikanskogo-samoletarjeb-grouler.html

65. Eurasia Daily, Can Iran's nuclear facilities be destroyed in a single strike? The Israeli experience, 7 August 2019.

66. https://eadaily.com/ru/news/2019/08/07/mozhno-li-unichtozhitiranskie-yadernye-obekty-odnim-udarom-izrailskiy-opyt

67. Sina newspaper, Sina newspaper, The third anti-ship missile appeared suddenly, with a range up to $700 \mathrm{~km}$, and the U.S. aircraft carrier will become an open target, 17/10/2020.

68. https://k.sina.com.cn/article_6433466398_17f76e81e00100sg4s.html ?cre $=$ tianyi $\&$ mod=pcpager_news $\& l o c=3 \& r=9 \& r f u n c=34 \& \mathrm{tj}=$ none $\& \mathrm{t}$ $r=9$

69. Sina newspaper, Sina newspaper, All obstacles failed, and the iranian arms embargo was lifted gradually! Russian experts analyze the weapons that iran will purchase, 21/10/2020.

70. https://n9.cl/y8h1d 